\title{
NONPOINT SOURCES OF PESTICIDES IN THE SAN JOAQUIN RIVER, CALIFORNIA: INPUT FROM WINTER STORMS, 1992-93
}

By Joseph L. Domagalski

U.S. GEOLOGICAL SURVEY

Open-File Report 95-165

NATIONAL WATER-QUALITY ASSESSMENT PROGRAM

$\bar{N}$
of

Sacramento, California

1995 


\section{U.S. DEPARTMENT OF THE INTERIOR BRUCE BABBITT, Secretary}

U.S. GEOLOGICAL SURVEY

Gordon P. Eaton, Director

Any use of trade, product, or firm names in this publication is for descriptive purposes only and does not imply endorsement by the U.S. Government.

For sale by the U.S. Geological Survey

Earth Science Information Center

Open-File Reports Section

Box 25286, MS 517

Denver Federal Center

Denver, CO 80225

For additional information write to:

District Chief

U.S. Geological Survey

Federal Building, Room W-2233

2800 Cottage Way

Sacramento, CA 95825 


\section{Foreword}

The mission of the U.S. Geological Survey (USGS) is to assess the quantity and quality of the earth resources of the Nation and to provide information that will assist resource managers and policymakers at Federal, State, and local levels in making sound decisions. Assessment of water-quality conditions and trends is an important part of this overall mission.

One of the greatest challenges faced by water-resources scientists is acquiring reliable information that will guide the use and protection of the Nation's water resources. That challenge is being addressed by Federal, State, interstate, and local water-resource agencies and by many academic institutions. These organizations are collecting water-quality data for a host of purposes that include: compliance with permits and water-supply standards; development of remediation plans for a specific contamination problem; operational decisions on industrial, wastewater, or water-supply facilities; and research on factors that affect water quality. An additional need for water-quality information is to provide a basis on which regional and national-level policy decisions can be based. Wise decisions must be based on sound information. As a society we need to know whether certain types of water-quality problems are isolated or ubiquitous, whether there are significant differences in conditions among regions, whether the conditions are changing over time, and why these conditions change from place to place and over time. The information can be used to help determine the efficacy of existing water-quality policies and to help analysts determine the need for and likely consequences of new policies.

To address these needs, the Congress appropriated funds in 1986 for the USGS to begin a pilot program in seven project areas to develop and refine the National Water-Quality Assessment (NAWQA) Program. In 1991, the USGS began full implementation of the program. The NAWQA Program builds upon an existing base of water-quality studies of the USGS, as well as those of other Federal, State, and local agencies. The objectives of the NAWQA Program are to:

-Describe current water-quality conditions for a large part of the Nation's freshwater streams, rivers, and aquifers.

- Describe how water quality is changing over time.

-Improve understanding of the primary natural and human factors that affect water-quality conditions.

This information will help support the development and evaluation of management, regulatory, and monitoring decisions by other Federal, State, and local agencies to protect, use, and enhance water resources.

The goals of the NAWQA Program are being achieved through ongoing and proposed investigations of 60 of the Nation's most important river basins and aquifer systems, which are referred to as study units. These study units are distributed throughout the Nation and cover a diversity of hydrogeologic settings. More than two-thirds of the Nation's freshwater use occurs within the 60 study units and more than twothirds of the people served by public water-supply systems live within their boundaries.

National synthesis of data analysis, based on aggregation of comparable information obtained from the study units, is a major component of the program. This effort focuses on selected water-quality topics using nationally consistent information. Comparative studies will explain differences and similarities in observed water-quality conditions among study areas and will identify changes and trends and their causes. The first topics addressed by the national synthesis are pesticides, nutrients, volatile organic compounds, and aquatic biology. Discussions on these and other water-quality topics will be published in periodic summaries of the quality of the Nation's ground and surface water as the information becomes available.

This report is an element of the comprehensive body of information developed as part of the NAWQA Program. The program depends heavily on the advice, cooperation, and information from many Federal, State, interstate, Tribal, and local agencies and the public. The assistance and suggestions of all are greatly appreciated.

Robert M. Hirsch

Chief Hydrologist 


\section{CONTENTS}

Abstract

Introduction

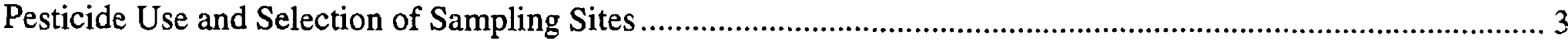

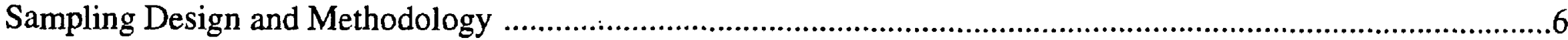

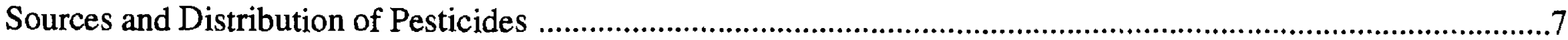

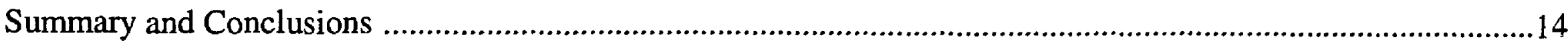

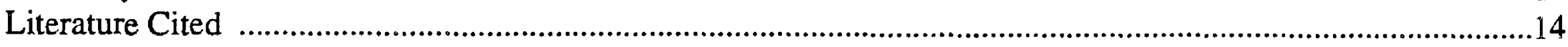

\section{FIGURES}

1,2. Maps showing:

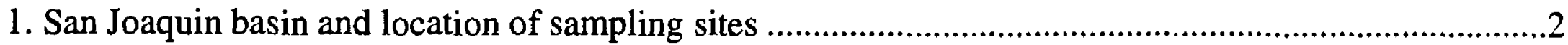

2. Diazinon use on almonds in the San Joaquin Valley, California, 1990 .............................................4

3-8. Graphs showing:

3. Monthly diazinon use on almonds in the San Joaquin Valley, California, 1990 ..................................5

4. Daily rainfall record at Modesto, California, January-February, 1993 …................................................5

5. Diazinon concentrations measured during weekly or twice weekly sampling at the San Joaquin River

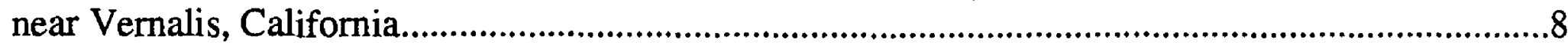

6. Specific conductance, diazinon concentrations, and discharge measured at Orestimba Creek, San

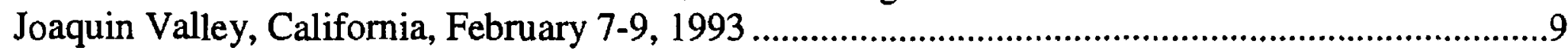

7. Discharge and diazinon concentrations is water samples from the Merced River, San Joaquin Valley, California, February 8-11, 1993

8. Discharge and diazinon concentrations in water samples from the San Joaquin River near Vernalis, California, February 1993.

\section{TABLES}

1. Reporting limits for pesticides analyzed by gas chromatography/mass selective detector, recoveries, and relative standard deviations

2. Summary of diazinon concentration during the storm of February $7-11,1993$

\section{CONVERSION FACTORS}

\begin{tabular}{rll}
\hline Multiply & By & To obtain \\
\hline cubic foot per second $\left(\mathrm{ft}^{3} / \mathrm{s}\right)$ & 0.02832 & cubic meter per second \\
pound, avoirdupois $(\mathrm{lb})$ & 0.4536 & kilogram \\
square mile $\left(\mathrm{mi}^{2}\right)$ & 2.590 & square kilometer \\
\hline
\end{tabular}

Temperature is given in degrees Celsius $\left({ }^{\circ} \mathrm{C}\right)$, which can be converted to Degrees Fahrenheit $\left({ }^{\circ} \mathrm{F}\right)$ by the following equation:

$$
{ }^{\circ} \mathrm{F}=1.8\left(^{\circ} \mathrm{C}\right)+32 \text {. }
$$




\title{
NONPOINT SOURCES OF PESTICIDES IN THE SAN JOAQUIN RIVER,
}

\section{CALIFORNIA: INPUT FROM WINTER STORMS, 1992-93}

\author{
By Joseph L. Domagalski
}

\begin{abstract}
Organophosphate insecticides, including chlorpyrifos, diazinon, and methidathion, are applied to dormant orchards in the San Joaquin Valley, California, during late December through January. This time frame coincides with the period of heaviest rainfall in the valley, and rainfall mobilizes a portion of these pesticides from the orchards. The pesticides enter the San Joaquin River and have been detected along the perennial reach of the river.
\end{abstract}

A storm on the evening of February 7 and the morning of February 8, 1993, deposited more than an inch and a half of rain in the San Joaquin Valley. Two distinct peaks of organophosphate pesticide concentrations were measured at the mouth of the San Joaquin River during a single rise in discharge. Both peaks were attributed to contrasts between the soil texture and hydrology of the eastern and western valley. The fine soil texture and small size of the western tributary basins contributed to rapid runoff. Diazinon concentrations peaked within hours after rainfall ended and then decreased because of a combination of dilution with pesticide-free runoff from the nearby Coast Ranges and decreased pesticide concentrations in the agricultural runoff. Data for the Merced River, a large tributary of the eastern San Joaquin Valley, are sparse, but indicate that peak concentrations occurred at least a day after those of the western tributary streams. That delay may be due to the presence of well- drained soils, the larger size of the drainage basins, and the management of surface-water drainage networks. Runoff from a subsequent storm, on February 18 and 19, contained significantly lower concentrations of most organophosphate pesticides, indicating that runoff from the first storm had already removed most of the pesticides available for rainfall-induced transport.

\section{INTRODUCTION}

Acetyl cholinesterase-inhibiting pesticides are used extensively in the San Joaquin Valley of California (fig. 1), an important agricultural region of the United States. These pesticides are used throughout the year, including the winter months when most rainfall occurs. Organophosphate pesticides affect nerve impulses in target organisms by acetyl cholinesterase inhibition (Buchel, 1983) and can be toxic to some aquatic organisms at concentrations less than one part per billion (Amato and others, 1992; Marshall and Roberts, 1978). Understanding the transport and concentration of the pesticides that are present in surface waters during the winter months is critically important so that effective control strategies can be implemented.

The occurrence of pesticides in surface waters has been reported by numerous authors, including Moody and Goolsby (1993), Pereira and Hostettler (1993), Pereira and Rostad (1990), Richards and Baker (1993), and Thurman and others, (1991). Most of the previous research, however, focused on organonitrogen herbicides, and most of the studies were done in the midwestern United States. These studies 


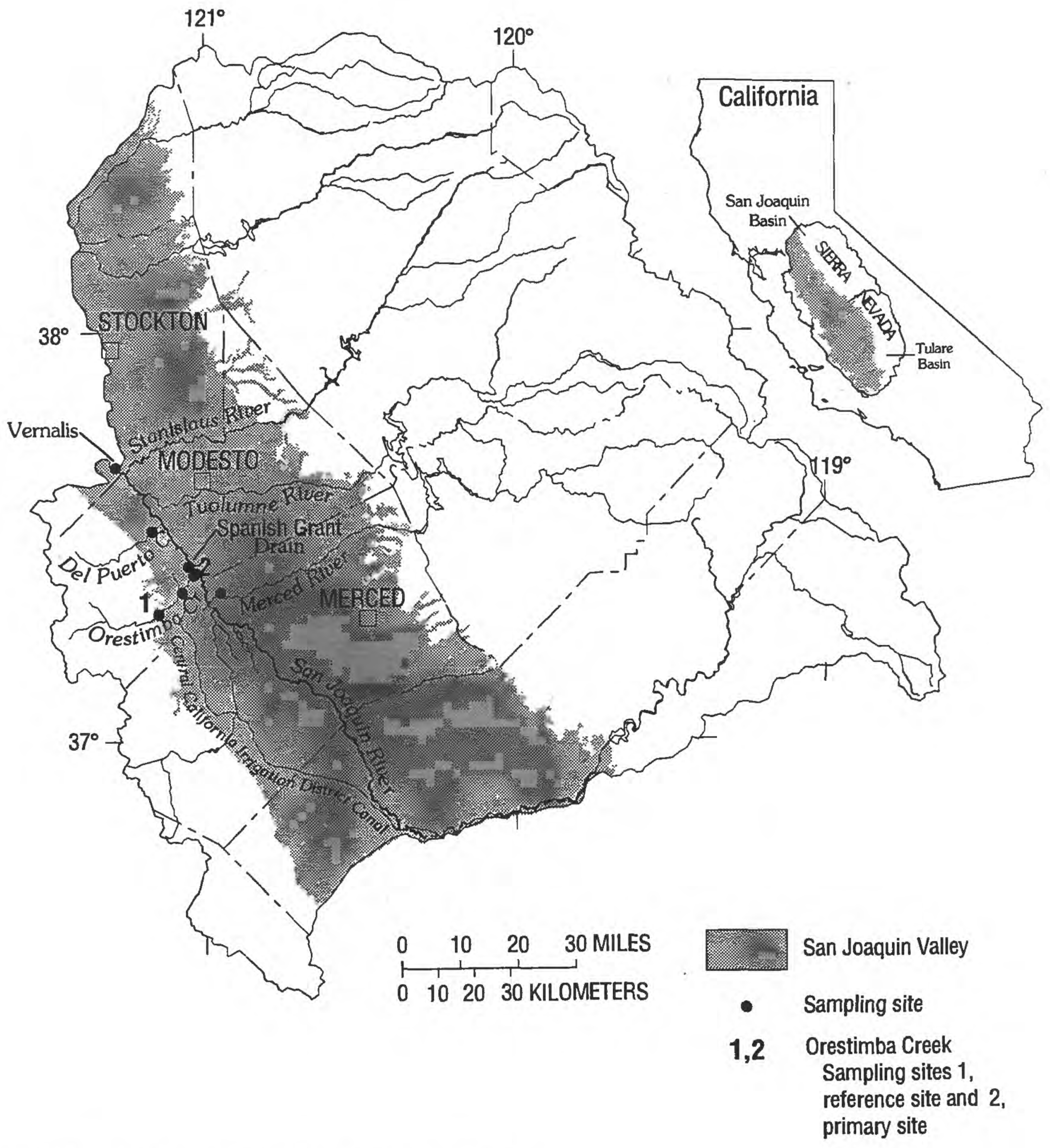

Figure 1. San Joaquin basin and location of sampling sites.

indicate that shortly after herbicide applications and following rainfall, surface-water concentrations and loads tend to be highest.

Relatively few studies have focused on organophosphate pesticides. Readman and others, (1992) attributed chlorpyrifos in near-shore marine sediments to runoff, and Domagalski and Kuivila (1993) reported on organophosphate and carbamate pesticides in an estuarine environment.

A study was done during December 1992 through February 1993 to measure the concentrations of organophosphate pesticides in the San Joaquin River and selected tributaries in the San Joaquin Valley. This report describes the sampling design used and 
identifies the occurrence of pesticides in the sampled streams and rivers. Most of the discussion in this report is of diazinon, the most frequently detected pesticide.

\section{PESTICIDE USE AND SELECTION OF SAMPLING SITES}

The principal organophosphate pesticides used on dormant orchards in the San Joaquin Valley include chlorpyrifos, diazinon, and methidathion. Dormant orchards are sprayed from December through February with most spraying in January. Detailed records of the actual amounts of various pesticides used on specific crops are kept by the California Department of Pesticide Regulation. The most recent data available are for 1990 applications (California Department of Pesticide Regulation, 1990). In that year, 51,000 pounds (lb) of chlorpyrifos, $160,000 \mathrm{lb}$ of diazinon, and $41,000 \mathrm{lb}$ of methidathion were used as dormant orchard sprays in the San Joaquin Valley, an area of approximately 12,000 square miles $\left(\mathrm{mi}^{2}\right)$. This application of pesticides to dormant orchards accounts for $13 \%$ of the chlorpyrifos, $58 \%$ of the diazinon, and $80 \%$ of the methidathion used for the entire year within the San Joaquin Valley. Only a part of those applications are within the drainage of the perennial San Joaquin River.

Almonds are the principal orchard crop in the San Joaquin Valley. The amount of diazinon applied to almond orchards during 1990 in the northern part of the valley is shown in figure 2 . The pesticide application map is plotted on a statistical basis at the geographic level of a township (36 $\left.\mathrm{mi}^{2}\right)$. The category of highest application, greater than $1,166 \mathrm{lb}$ of diazinon applied during 1990, is the upper quartile (above 75\%). The second highest application category, 242 to $1,165 \mathrm{lb}$ applied, is the quartile from the median to $75 \%$. The second lowest application category, 89 to $241 \mathrm{lb}$ applied, is the quartile from the median to $25 \%$. The lowest application category, zero to $88 \mathrm{lb}$ applied, is the lower quartile (below 25\%).

A plot of the timing of diazinon applications is shown in figure 3 . The actual times of application are based on management decisions, such as the timing of rainfall and the approximation of when the trees will blossom. Applications made too late in the season can be harmful to the blossoms, as the oils contained in the sprays can cause burning. Dormant-orchard pesticides are applied by tractor-mounted rigs, but spraying generally is not possible in water-saturated fields. In late 1992 and early January 1993, a series of rainstorms (fig. 4) prevented most spraying until the last week of January. Although some spraying was done in December, most pesticides were applied during a narrow window of time, after January 21.

Sampling sites were chosen on the basis of physiography and land-use. Small drainage basins provide information on pesticide input from specific land uses or physiographic horizons. The larger drainage basins of major rivers provide information on multiple sources of contaminants. As indicated by the pesticide-use map (fig. 2), orchards are in the eastern and western parts of the San Joaquin Valley. The pesticide-use map also shows that most orchards are east of the San Joaquin River. The perennial San Joaquin River is the reach directly upstream from the confluence with the Merced River (fig. 1). Flow along the remaining part of the San Joaquin River within the San Joaquin Valley is intermittent due to diversion of water for irrigation from reservoirs in the lower Sierra Nevada. The southern part of the San Joaquin Valley, which lies within the Tulare Basin (fig. 1, inset), has closed drainage, and all surfacewater streams are ephemeral. Therefore, no attempt was made to include the southern San Joaquin Valley in the surface-water sampling design.

The major physiographic consideration for selecting sampling sites in the northern San Joaquin Valley is sediment provenance. Soils of the western valley are derived from the sedimentary rocks of the Coast Ranges. These rocks generally are marine shales; the soils derived from these shales are fine grained and easily weathered. The soils of the eastern valley are derived from the Sierra Nevada batholith. These soils generally are more coarse grained and allow more rapid infiltration of rain or irrigation water.

The primary site in the western San Joaquin Valley was Orestimba Creek. The primary sampling site on Orestimba Creek is labeled as site 2 on figure 1. The 


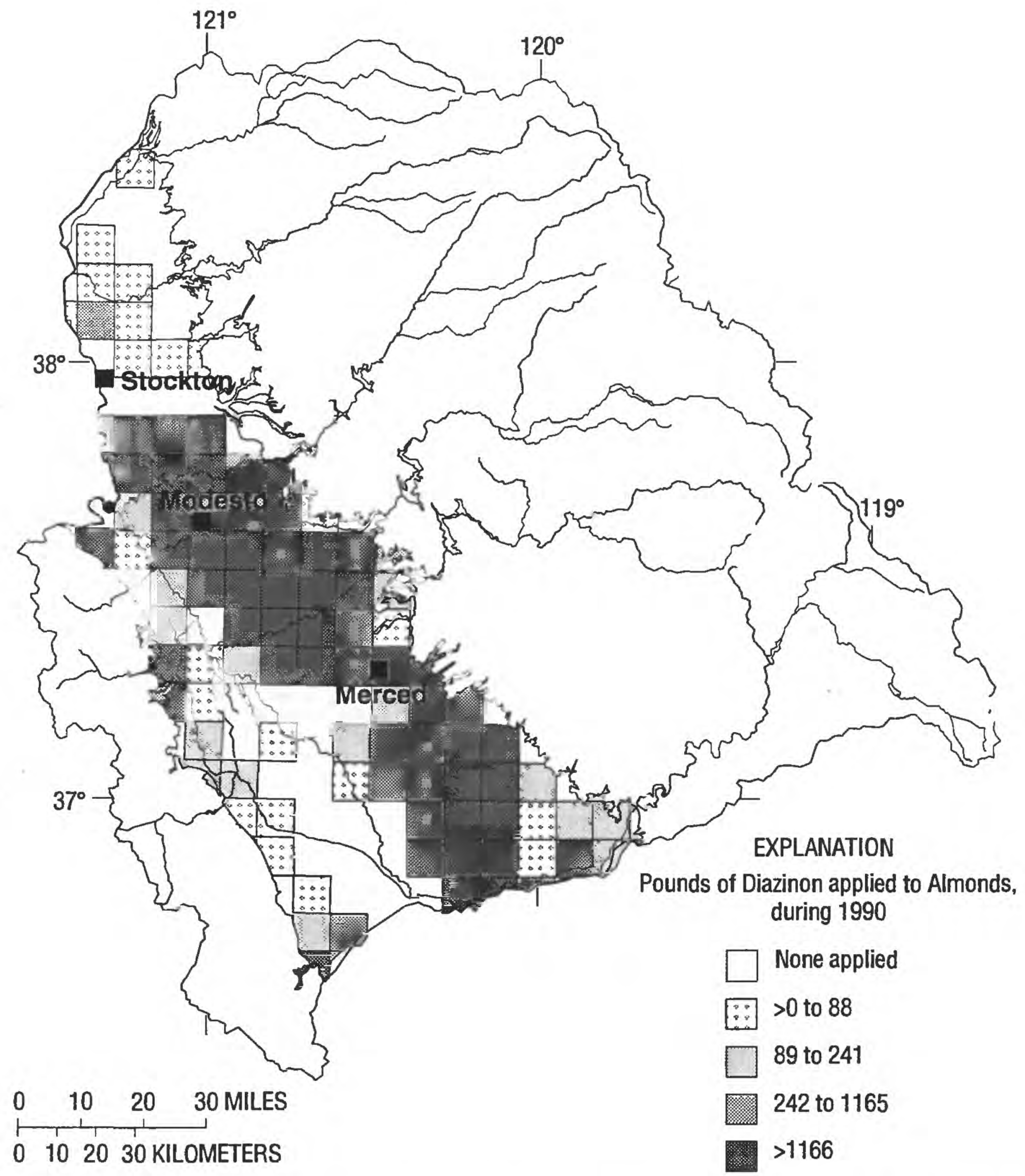

Figure 2. Diazinon use on almonds in the San Joaquin Valley, California, 1990 (California Department of Pesticide Regulation, 1990).

alternate site, a reference site on Orestimba Creek, is above the San Joaquin Valley, within the Coast Ranges (site 1, fig. 1). All sampling at Orestimba Creek, unless otherwise stated, was done at site 2. Land use in the Orestimba Creek drainage, an alluvial fan of the Coast Ranges, is mixed agriculture. Orestimba Creek is an ephemeral stream that flows during the winter in response to rainfall and during the summer in response to irrigation runoff. Input to the creek might be locally derived, but during intense storms, water flows from the adjacent Coast Ranges.

Additional sites were selected in the western part of the valley to increase aerial coverage and to facil- 


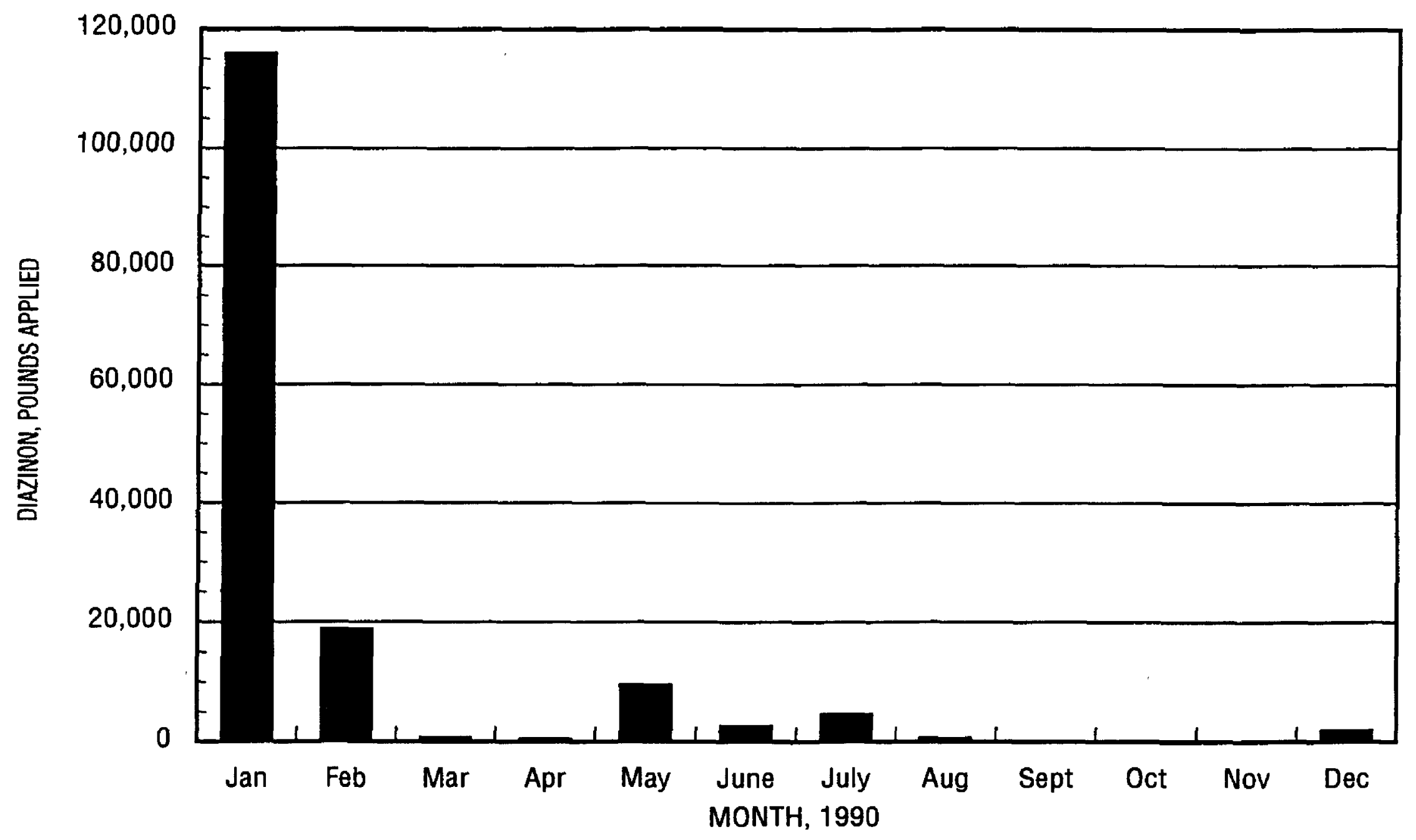

Figure 3. Monthly diazinon use on almonds in the San Joaquin Valley, California, 1990 (California Department of Pesticide Regulation, 1990).

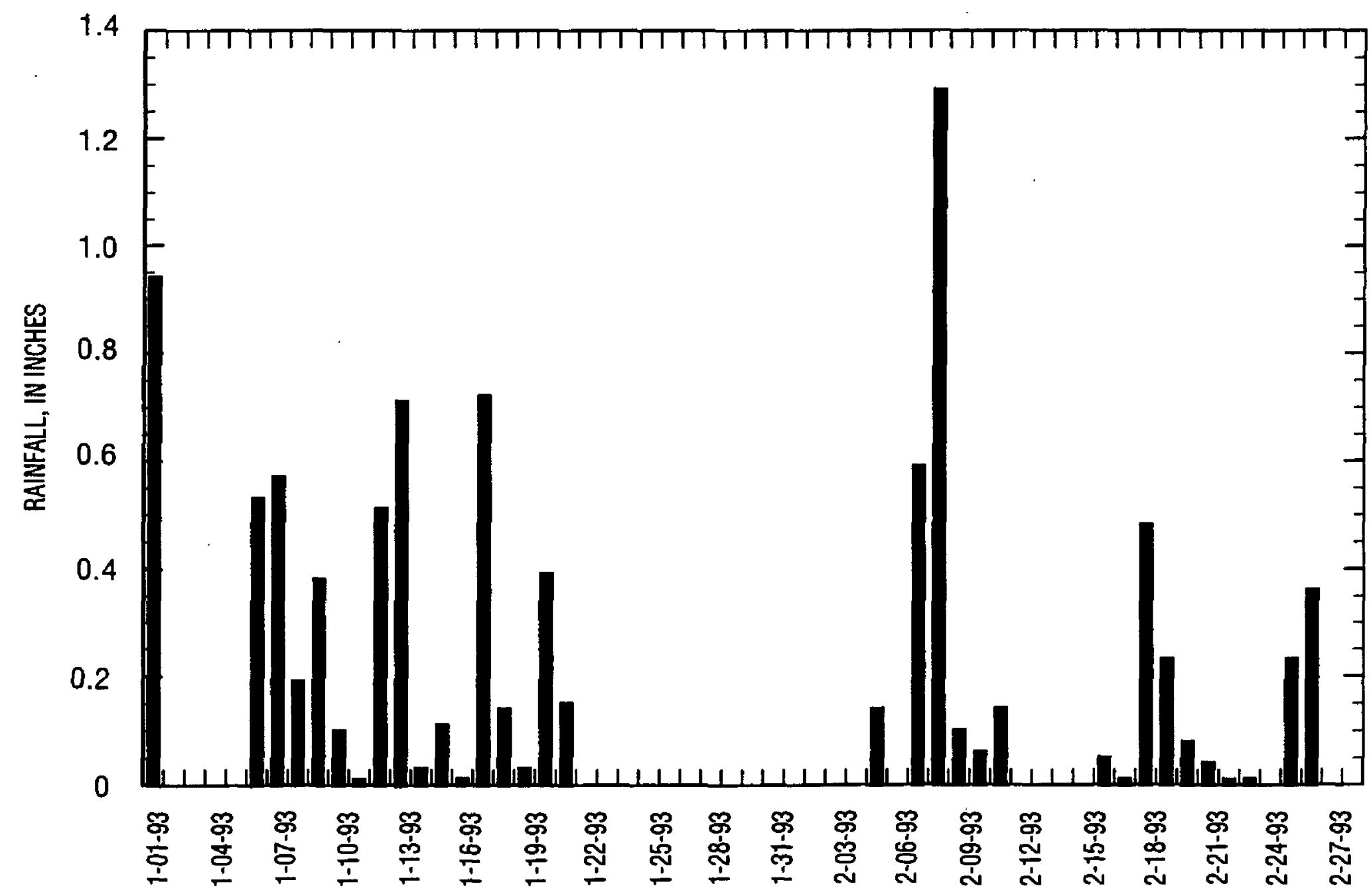

Figure 4. Daily rainfall record at Modesto, California, January-February, 1993. 
itate data interpretation. Additional sites were selected to determine if these small drainages would have a similar reaction to rainfall with respect to pesticide transport. The additional sites are the Central California Irrigation District Canal, Del Puerto Creek, and the Spanish Grant Drain (fig. 1).

Drainage of the eastern San Joaquin Valley is dominated by relatively large rivers, such as the Merced, Tuolumne, and Stanislaus Rivers (fig. 1). Orchard land use is extensive within the drainages of these three rivers. The Merced River was chosen as representative of pesticide input from the eastern San Joaquin Valley. Land use upstream of the Merced River site is representative of agriculture on alluvial fans in the eastern San Joaquin Valley. One site was chosen on the San Joaquin River, just downstream from the Stanislaus River, at Vernalis. This location, considered the mouth of the San Joaquin River, is the most downstream site that is above the tidal prism of the San Francisco Bay Estuary.

Although pesticide application patterns indicate that the eastern valley.may be the principal source of pesticides to the San Joaquin River, physiographic controls may prevent much of the orchard runoff of the eastern valley from reaching the river except during intense rainfall. Rain or irrigation water infiltrates rapidly through the eastern valley soils, which are derived from granitic alluvium, and there is less runoff. Although there is less orchard acreage in the western valley, rapid runoff from the finegrained soils may permit greater loading to the San Joaquin River.

\section{SAMPLING DESIGN AND METHODOLOGY}

The overall sampling design addressed the temporal and spatial variability in pesticide concentration at sites that were expected to be sources of pesticides to the San Joaquin River. In addition, pesticide concentrations were measured at Vernalis, the most downstream location of the San Joaquin River.

The sampling was done by scientists in two research groups of the U.S. Geological Survey-the National Water Quality Assessment (NAWQA) program and the San Francisco Bay Toxics Substances Hydrology Program. The objective of the NAWQA program was to assess pesticide input to the San Joaquin River from various and specific land uses within relatively homogeneous physiographic provinces. The objective of the San Francisco Bay program was to examine pesticide loadings to the estuary.

As part of the NAWQA program, the Orestimba Creek site was sampled twice each week; the additional western valley sites, the Merced River and the San Joaquin River, were sampled once each week from mid-December until the end of February. The greater sampling frequency at Orestimba Creek was to assess short-term variability in concentrations of pesticides. In addition to the fixed-interval temporal sampling, selected sites were sampled during two storms to obtain information about concentration variability during rainfall and runoff at single sites. Initially, the Orestimba Creek site and the Merced River site were designed for storm hydrograph sampling. However, logistical difficulties prevented the simultaneous sampling of both sites during the two storms. Samples were collected over the complete hydrograph at Orestimba Creek for two storms, and over part of the hydrograph for one storm at the Merced River site. The San Joaquin River site was sampled by the San Francisco Bay program throughout the dormant-orchard period. The sampling scheme was to collect daily samples between storms and twice daily samples during a storm.

All samples were collected using width- and depth-integrated sampling procedures adapted for organic contaminants. Samples were collected from the small streams by wading the cross section, selecting equal-width increments, and depth integrating the sample collection using an isokinetic sampler. The complete method is described by Edwards and Glysson (1988). The composite samples were split for various constituent analyses using a Geotech cone splitter, constructed of Teflon ${ }^{\circledR}$. One-liter samples for pesticide analysis were filtered through glass-fiber filters (Whatman GF/F) housed in an aluminum filter support. The filters were baked at $450^{\circ} \mathrm{C}$ prior to use. The water was pumped through the filter with a Cole-Parmer Teflon ${ }^{\circledR}$ diaphragm pump head and a Masterflex pump drive. Solid-phase 
Table 1. Reporting limits for pesticides analyzed by gas chromatography/mass selective detector, recoveries, and relative standard deviations (Peter F. Rogerson, National Water Quality Laboratory, written commun., 1944)

$[\mu \mathrm{g} / \mathrm{L}$, microgram per liter, $\%$, percent $]$

\begin{tabular}{lccc}
\hline Pesticide & $\begin{array}{c}\text { Reporting } \\
\text { limit } \\
(\mu \mathrm{g} / \mathrm{L})\end{array}$ & $\begin{array}{c}\text { Recovery } \\
(\%)\end{array}$ & $\begin{array}{c}\text { Relative } \\
\text { standard } \\
\text { deviation } \\
(\%)\end{array}$ \\
\hline Chlorpyrifos & 0.005 & 107 & 17 \\
Diazinon & .008 & 115 & 18 \\
Methidathion & .03 & 90 & 10 \\
Parathion & .022 & 114 & 13 \\
Metolachlor & .009 & 133 & 19 \\
Carbarly & .046 & 69 & 41 \\
Atrazine & .017 & 104 & 17 \\
Cyanazine & .013 & 116 & 22 \\
Simazine & .008 & 93 & 15 \\
Trifluralin & .012 & 97 & 12 \\
Alachlor & .009 & 122 & 16 \\
Dacthal & .004 & 110 & 17 \\
Napropamide & .01 & 129 & 15 \\
DDE & .01 & 82 & 7 \\
\hline
\end{tabular}

extraction of the water samples followed, using Varian 500-mg $\mathrm{C}_{18}$ cartridges. The cartridges were pretreated with 2 milliliters $(\mathrm{mL})$ of methanol and 2 $\mathrm{mL}$ of pesticide-free water. Prior to extraction, the water samples were fortified with $1 \%$ methanol, and 100 nanograms (ng) each of three surrogate compounds (terbutylazine, deuterated lindane, and deuterated diazinon) were added to assess the general effectiveness of the extraction and analysis method. The water samples were pumped through the cartridges with a direct-current, ceramic-piston, valveless metering pump from Fluid-Metering Incorporated (catalog identification: RHBOCKE). All parts that had contact with the water were either Telflon ${ }^{\circledR}$ or ceramic. The flow rate of water through the cartridge was 25 to 30 milliliters per minute (mL/ min).
The cartridges were dried with a gentle stream of either carbon dioxide or nitrogen and were then eluted with a mixture of hexane and isopropanol (3:1). Internal standards were added, and the solvent was concentrated to a volume of 100 microliters $(\mu 1)$. The samples collected at Orestimba Creek and Merced River, along with the temporal sampling of the San Joaquin River at Vernalis, were analyzed by gas chromatography-mass selective detector (Hewlett-Packard). A partial list of pesticides analyzed, along with reporting limits and recoveries, is shown in table 1. For samples collected at Del Puerto Creek, Spanish Grant Drain, the Central California Irrigation District Canal, and the storm sampling of the San Joaquin River at Vernalis, analysis was by gas chromatography/ion trap detector (Finnigan). These samples were extracted according to a similar methodology, as described by Crepeau and others, (1994). The principal difference between the two methods was the type of mass spectrometer used.

\section{SOURCES AND DISTRIBUTION OF PESTICIDES}

Diazinon concentrations, measured weekly or every other week at the San Joaquin River near Vernalis, are shown in figure 5. The data point for December 16, 1992, shows the low background concentration prior to spraying. Diazinon concentrations at this site increased during January. The highest January concentration was measured in the water sample collected on January 13 following a 2day storm when more than an inch of rainfall was recorded (fig. 4). The sources of the pesticides to the San Joaquin River during January are unknown. Measured concentrations at all sites in the western San Joaquin Valley, including Orestimba Creek, Del Puerto Creek, the Spanish Grant Drain, and the Central California Irrigation District Canal were less than those for the San Joaquin River. Diazinon concentrations in samples collected from the Merced River in January ranged from 0.053 to 0.077 micrograms per liter $(\mu \mathrm{g} / \mathrm{L})$. These measured concentrations were higher than those measured in the tributaries of the western San Joaquin Valley, but were not high enough to account for the concentrations measured at the San Joaquin River during January. 


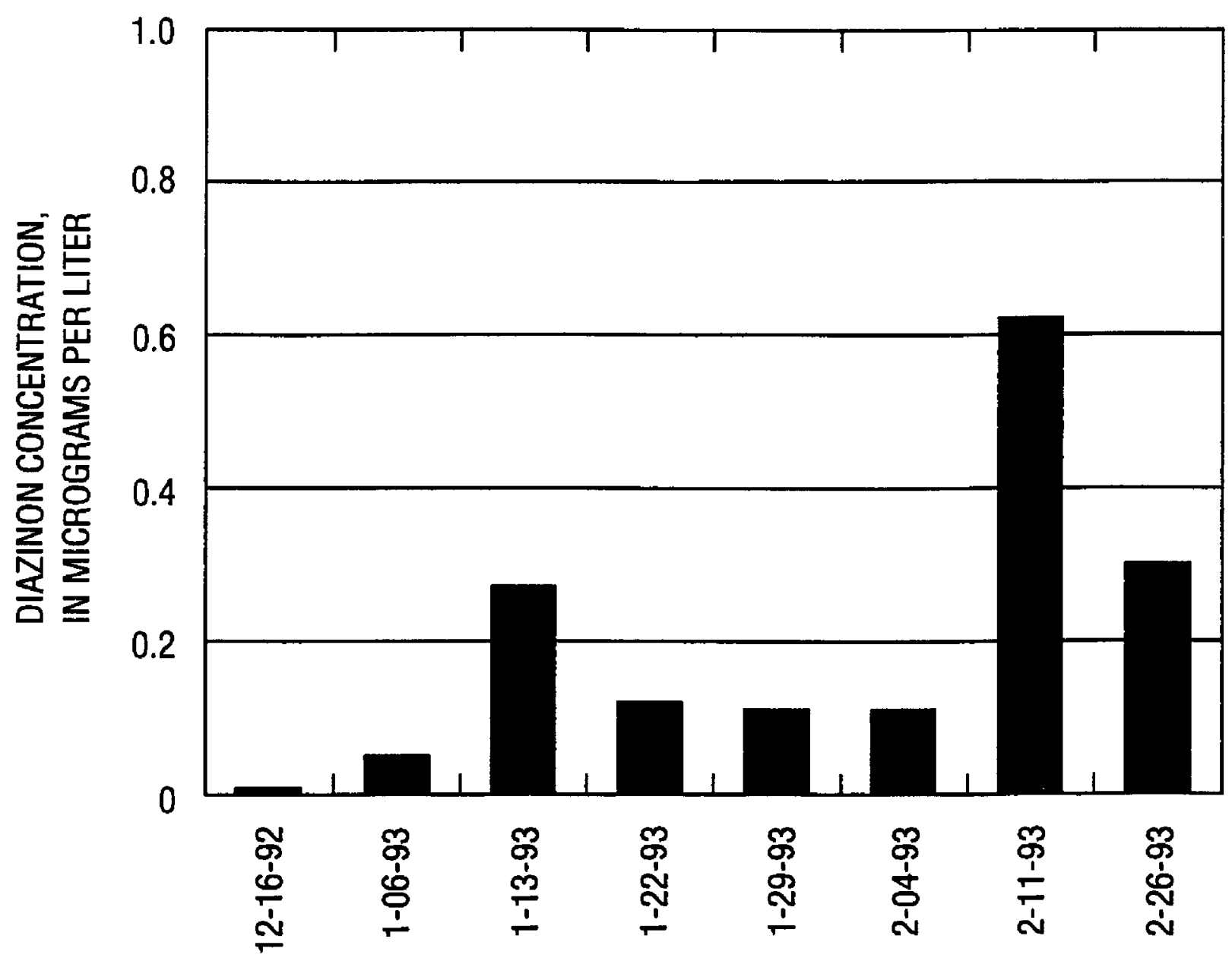

Figure 5. Diazinon concentrations measures during weekly or every other week sampling at the San Joaquin River near Vernalis, California.

As shown in figure 4, there was no rainfall between January 21 and February 5. The lack of rainfall allowed the fields to drain sufficiently for pesticides to be applied to the dormant orchards. The highest daily rainfall began with a storm on February 7. Plots of specific conductance and discharge and diazinon concentrations and discharge during the February 7-9 storm are shown in figure 6. Orestimba Creek had no flow prior to this rainfall. Discharge increased slowly on February 7 and throughout much of February 8. Specific conductance was initially high but then decreased and showed considerable variation for a few hours as discharge increased. This variation in conductivity suggests that a combination of rainwater and drainage from various fields with different major element chemistry was entering the stream. Specific conductance began to rise with discharge on the morning of February 8 , peaked at 1600 hours, and then decreased rapidly with the steep rise in the hydrograph. Most of the water at peak discharge originated from the Coast Ranges, as indicated by discharge records from the reference site, Orestimba Creek near Newman (site 1, fig. 1), and by low specific conductance. The rise in specific conductance at mid-morning on February 8 is inter- preted as the result of locally derived runoff from fields to Orestimba Creek. The drop in specific conductance with the steep rise of the hydrograph is interpreted as the input of relatively fresh water from the adjacent Coast Ranges.

The first sample for pesticide analysis was collected at 1000 hours on the morning of February 8 . The diazinon concentration in this sample was 0.54 $\mu \mathrm{g} / \mathrm{L}$ at a discharge of 170 cubic feet per second $\left(\mathrm{ft}^{3} / \mathrm{s}\right)$ (table 2). Concentrations of diazinon then increased rapidly over a period of several hours. Within 2 hours, the concentration had increased to $1.7 \mu \mathrm{g} / \mathrm{L}$, and within 5 hours, the maximum concentration of 3.8 $\mu \mathrm{g} / \mathrm{L}$ was observed at a discharge of $240 \mathrm{ft}^{3} / \mathrm{s}$. At 1900 hours, a concentration of $0.7 \mu \mathrm{g} / \mathrm{L}$ was measured; this sample was taken at the start of the steepest rise of the hydrograph at a discharge of 450 $\mathrm{ft}^{3 / 3}$. Discharge then increased rapidly and peaked at $1,280 \mathrm{ft}^{3} / \mathrm{s}$ just after midnight. The next sample was taken on February 9, at 1315 hours, during the declining part of the hydrograph. The diazinon concentration was $0.14 \mu \mathrm{g} / \mathrm{L}$.

The rise in diazinon concentrations from 0.54 to $3.8 \mu \mathrm{g} / \mathrm{L}$ is attributable to runoff from orchards within 

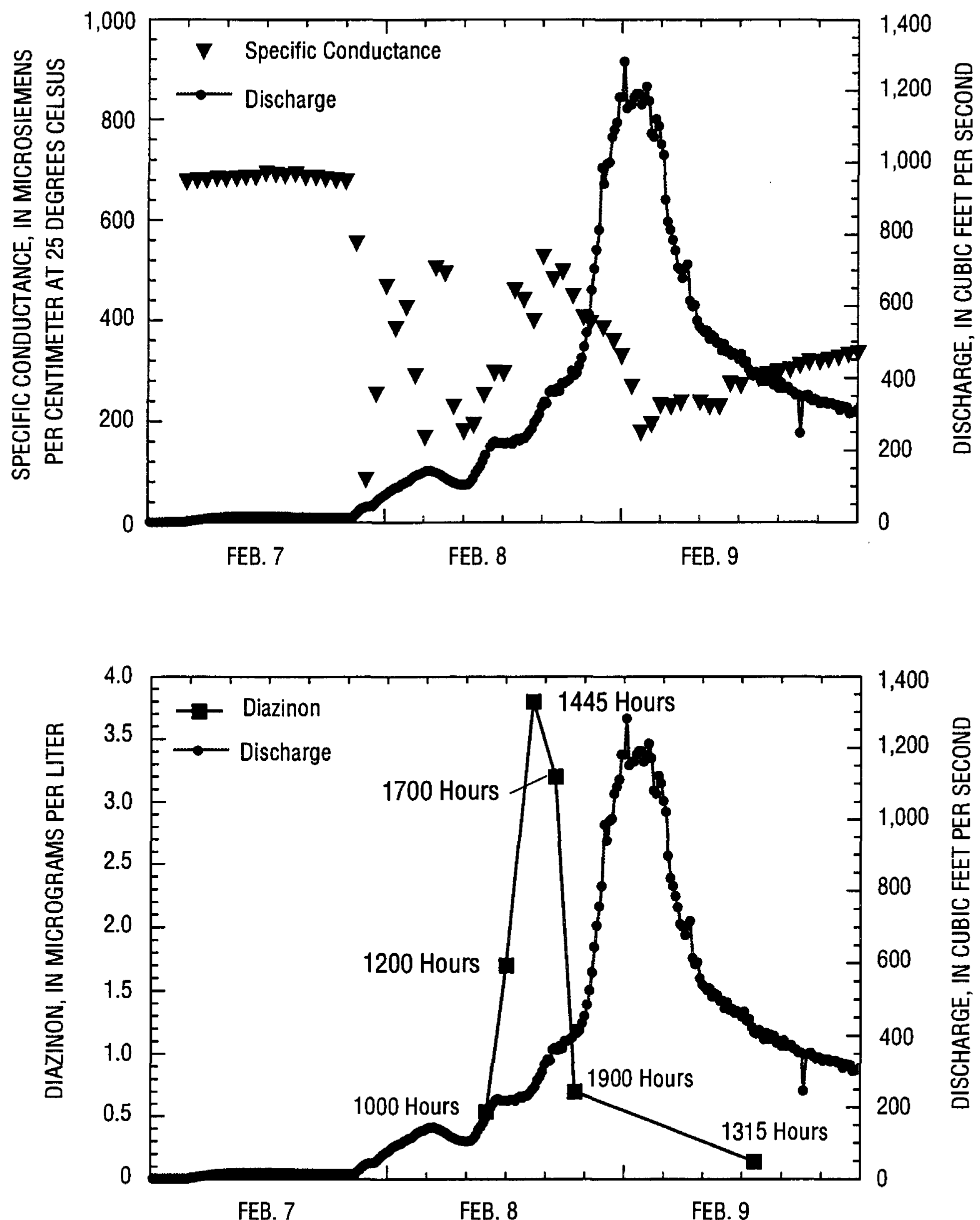

Figure 6. Specific conductance, diazinon concentrations, and discharge measured at Orestimba Creek, San Joaquin Valley, California, February 7-9, 1993.

the Orestimba Creek drainage. The drop in concentration from 3.8 to $0.7 \mu \mathrm{g} / \mathrm{L}$ occurred when there was only a modest decrease, approximately $20 \%$, in specific conductance and a modest increase, approximately $30 \%$, in discharge. Therefore, the diazinon concentration was decreasing before most drainage from the Coast Ranges reached this site. The implication is that the initial flush of field drainage had transported most of the diazinon that was available to be mobilized from the orchards. Although no samples were taken at peak discharge, it was assumed that the concentra- 
Table 2. Summary of diazinon concentration during the storm of February $7-11,1993$

( $\mu \mathrm{g} / \mathrm{L}$, microgram per liter)

\begin{tabular}{|c|c|c|c|c|}
\hline Location & $\begin{array}{c}\text { Date } \\
\text { measured }\end{array}$ & Time & $\begin{array}{c}\text { Diazinon } \\
\text { concentration } \\
(\mu \mathrm{g} / \mathrm{L})\end{array}$ & $\begin{array}{c}\text { Chlorpyrifos } \\
\text { concentration } \\
(\mu \mathrm{g} / \mathrm{L})\end{array}$ \\
\hline \multirow[t]{6}{*}{ Orestimba Creek } & $2 / 8$ & 1000 & 0.54 & 0.12 \\
\hline & & 1200 & 1.7 & .058 \\
\hline & & 1445 & 3.8 & .041 \\
\hline & & 1700 & 3.2 & .025 \\
\hline & & 1900 & .7 & .013 \\
\hline & $2 / 9$ & 1315 & .14 & .01 \\
\hline \multirow[t]{2}{*}{ Del Puerto Creek } & $2 / 8$ & 1315 & 5.4 & $<.025$ \\
\hline & $2 / 9$ & 1030 & .12 & $<.025$ \\
\hline \multirow[t]{2}{*}{ Spanish Grant Drain } & $2 / 8$ & 1500 & 1.6 & $<.025$ \\
\hline & $2 / 9$ & 1205 & .3 & $<.025$ \\
\hline \multicolumn{5}{|l|}{ Central California } \\
\hline \multirow[t]{2}{*}{ Irrigation District Canal } & $2 / 8$ & 1630 & 7.0 & $<.025$ \\
\hline & $2 / 9$ & 1430 & .4 & $<.025$ \\
\hline \multirow[t]{5}{*}{ Merced River } & $2 / 8$ & 1100 & .12 & .045 \\
\hline & & 1300 & .14 & .048 \\
\hline & & 1345 & .12 & .047 \\
\hline & $2 / 9$ & 1100 & .5 & .083 \\
\hline & $2 / 11$ & 1100 & 2.5 & .26 \\
\hline
\end{tabular}

tions would be less than $0.7 \mu \mathrm{g} / \mathrm{L}$. Runoff from the Coast Ranges provided a source of dilution water. A parcel of water in Orestimba Creek that enters the valley from the adjacent Coast Ranges (site 1, fig. 1) should reach the sampling site (site 2, fig. 1) in about 7 hours. The travel time was determined from an examination of the gaging station records at both sites (fig. 1). Peak flow from the Coast Ranges would dilute pesticide concentrations significantly within this 7-hour window.

Other tributaries of the western San Joaquin Valley had a temporal pattern of diazinon concentration during this storm similar to that at Orestimba Creek. The concentrations measured at Del Puerto Creek, the Spanish Grant Drain, and the Central California Irrigation District Canal are listed in table
2. The general pattern of diazinon concentration in the western San Joaquin Valley was high concentrations in samples collected early in the storm and declining concentrations as the storm progressed. These declines were attributed to the influx of relatively uncontaminated water from the nearby Coast Ranges or to the depletion of pesticides from the fields.

Of all the western valley sites, only the Orestimba Creek site had detectable concentrations of chlorpyrifos. The highest concentration of chlorpyrifos, 0.12 $\mu \mathrm{g} / \mathrm{L}$, was measured in the first sample collected. The lack of detections at other western valley sites is consistent with the pesticide-use data, which indicate only minor applications of chlorpyrifos in the western San Joaquin Valley. 
The hydrograph for the Merced River for the February 7-8 storm is shown in figure 7. The major physical difference between the Merced River and Orestimba Creek is the basin size and, hence, the response time of the river to the rainfall and runoff. Another difference between the two basins is that flow on the lower Merced River, within the San Joaquin Valley, normally is controlled by managed releases from an upstream reservoir. The rise in discharge shown in figure 7 is attributed to valleyderived runoff, as indicated from flow records at the reservoir and at the downstream sampling site. Peak discharge at the lower Merced River site is attributed to valley runoff and not to runoff from the adjacent Sierra Nevada. The response of the Merced River hydrograph to rainfall was delayed by more than a day relative to the Orestimba Creek hydrograph. Peak discharge on the Merced River was observed near 1200 hours on February 10, whereas peak discharge on Orestimba Creek was observed at 0015 hours on February 9, a difference of almost 36 hours.
The Merced River was sampled on February 8, and concentrations of diazinon and chlorpyrifos are shown in table 2. These measurements were made on the flat part of the hydrograph. Pesticide concentrations would be expected to remain constant because runoff had not been detected at this station, and flow was constant. The next sample was collected on February 9 at 1100 hours as the hydrograph showed an initial rise. The concentration of diazinon increased to $0.5 \mu \mathrm{g} / \mathrm{L}$ and chlorpyrifos increased to 0.083 . The next sample was not taken until February 11 , on the declining part of the hydrograph. The diazinon concentration was $2.5 \mu \mathrm{g} / \mathrm{L}$ (fig. 7 ), and chlorpyrifos was $0.26 \mu \mathrm{g} / \mathrm{L}$. This sample is particularly noteworthy because it indicates that the concentrations of diazinon and chlorpyrifos may have been considerably higher on the rising part of the hydrograph or near peak discharge. Previous research on pesticides transported from agricultural fields as a result of rainfall-induced runoff has indicated that peak concentrations generally occur prior to or near

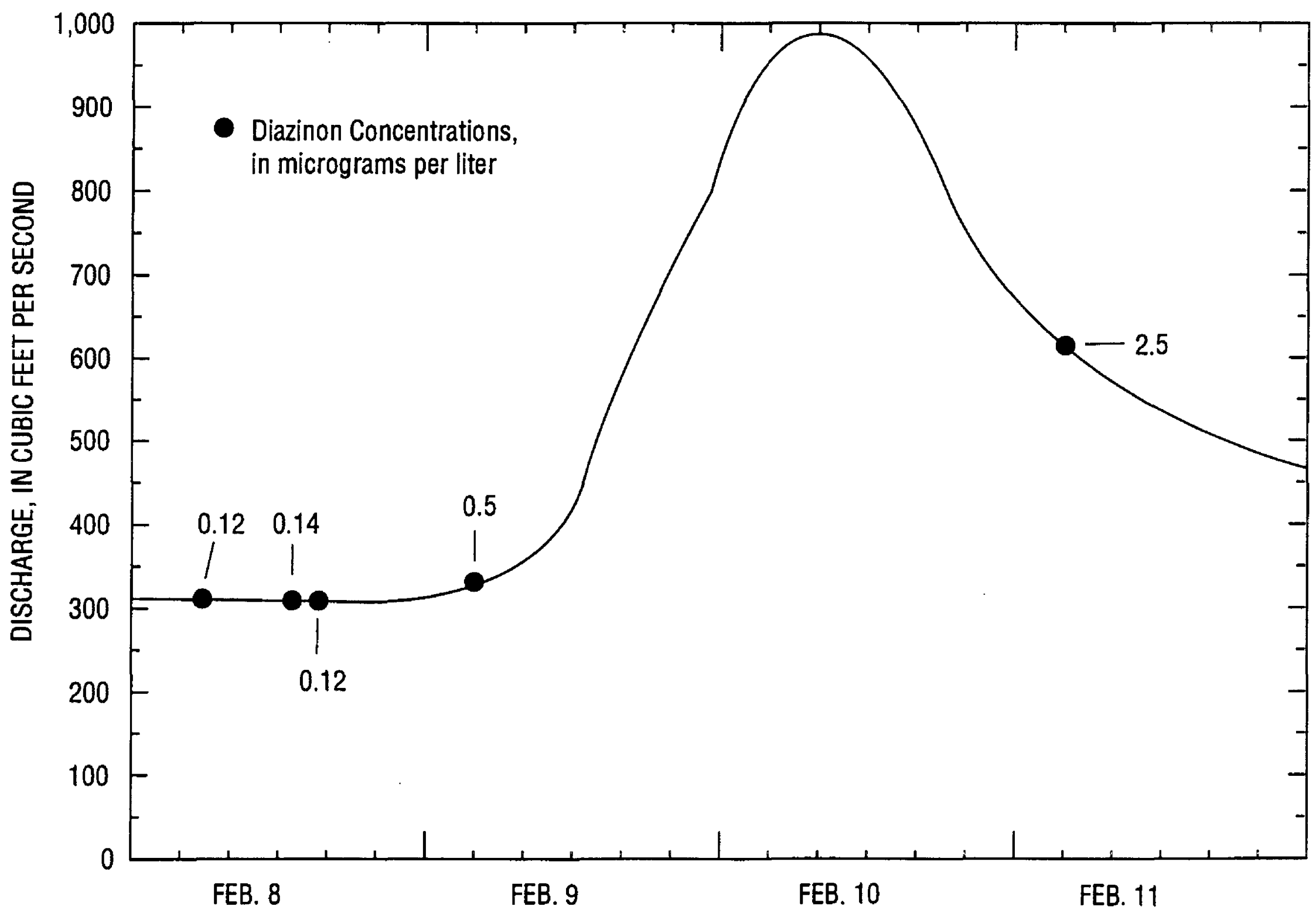

Figure 7. Discharge and diazinon concentrations in water samples from the Merced River, San Joaquin Valley, California, February 8-11, 1993. 
peak discharge (Richards and Baker, 1993; Thurman and others, 1991).

A plot of diazinon concentrations and discharge for the San Joaquin River is shown in figure 8. The diazinon plot shows two peaks in measured concentrations between February 8 and February 12. Both peaks were observed during a single storm. The first peak concentration of diazinon, $0.77 \mu \mathrm{g} / \mathrm{L}$, was in a water sample collected at about 2400 hours on February 8, and the second peak concentration, 1.07 $\mu \mathrm{g} / \mathrm{L}$, was in a sample collected at about 1900 hours on February 11. The data set indicates a variation in the loadings of diazinon to the San Joaquin River during the storm. As discussed previously, the hydrologic and chemical responses of the western tributaries preceded those of the eastern tributaries during this storm. Therefore, the first and second concen- tration peaks are probably the result of input from tributaries of the western and eastern San Joaquin Valley, respectively.

The first peak concentration of diazinon in the San Joaquin River occurred shortly before midnight on February 8. Loading from Del Puerto Creek and other tributaries and drains of the western San Joaquin Valley probably are responsible for the first peak in diazinon concentration. A diazinon concentration of $5.4 \mu \mathrm{g} / \mathrm{L}$ was measured at the Del Puerto Creek site at 1315 hours on February 8. Because only one sample was collected, the maximum concentration is unknown. On the basis of measured velocity in the San Joaquin River, which has been confirmed by a dye-tracer test during a similar flow regime, a parcel of water would take approximately 12 to 15 hours to travel from the Del Puerto Creek site to the San

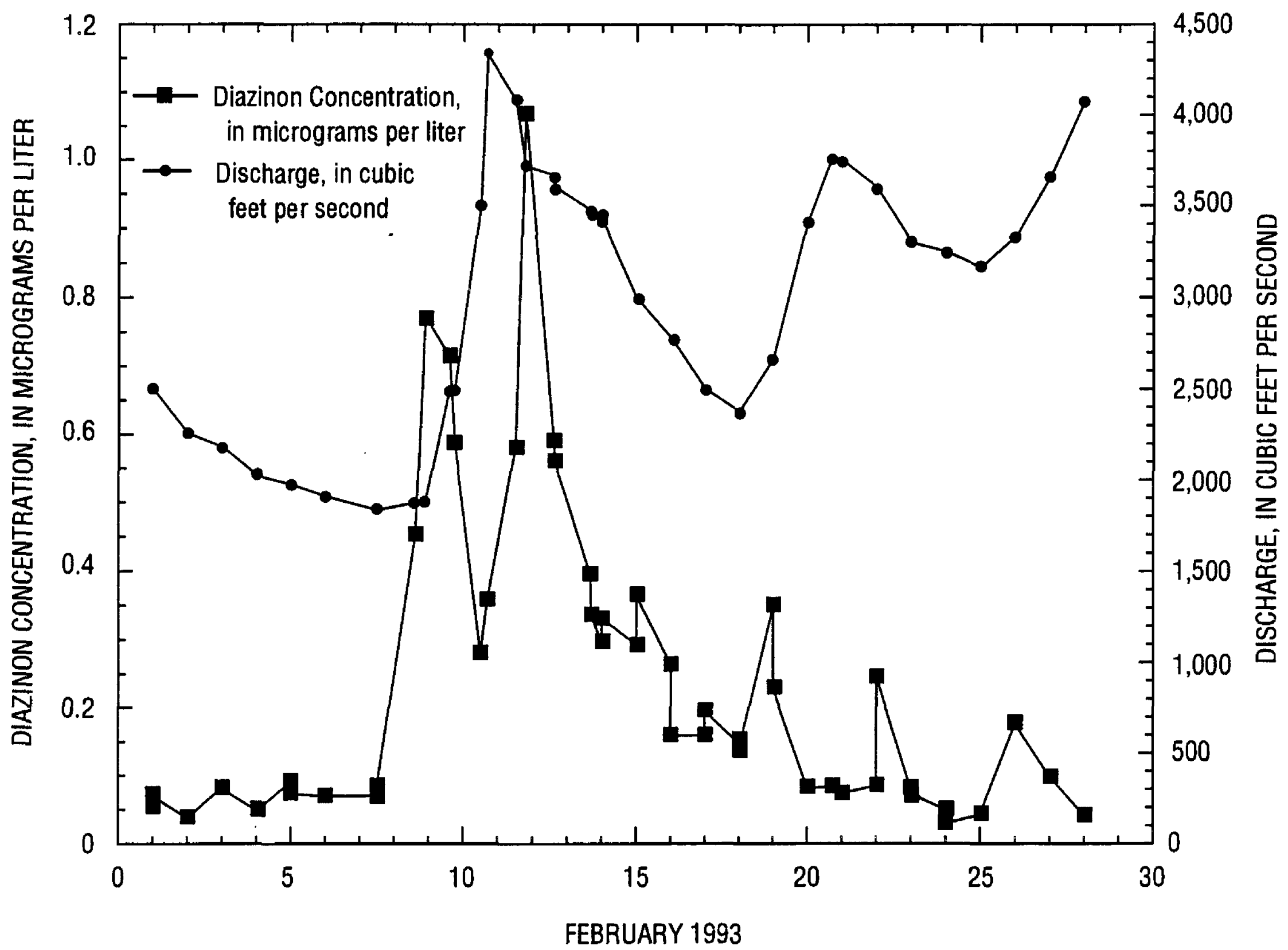

Figure 8. Discharge and diazinon concentrations in water samples from the San Joaquin River near Vernalis, California, February 1993. 
Joaquin River near Vernalis site. At about midnight on February 8, peak discharge occurred in the tributaries of the western San Joaquin Valley, along with a probable decrease in concentrations of diazinon. A decrease in diazinon concentrations in the western tributaries also should result in a decrease in concentrations at the San Joaquin River near Vernalis site.

The second peak concentration of diazinon in the San Joaquin River occurred at 1900 hours on February 11. At 1900 hours on February 9, the hydrograph for the Merced River was in the middle of the rising limb. Therefore, if the diazinon concentrations in the rising limb of the Merced River hydrograph were high, between 5 and $7 \mu \mathrm{g} / \mathrm{L}$, the river could be the source of the second peak concentration of diazinon observed at the San Joaquin River near Vernalis. This hypothesis has not been tested, but is based on measured velocities in the Merced River and a tracer test conducted under a similar flow regime, which determined that the approximate travel time of a parcel of water from the Merced River sampling site to the sampling site on the San Joaquin River is 2 days. A diazinon concentration of $2.5 \mu \mathrm{g} / \mathrm{L}$ was measured on the falling limb of the Merced River hydrograph, and, because pesticide concentrations generally are lower on the falling limb (Richards and Baker, 1993), concentrations probably were higher on the rising limb.

Two other possible major sources of pesticides to the San Joaquin River, the Tuolumne and the Stanislaus Rivers, were sampled near peak discharge, about the same time as the peak for the Merced River. The concentrations of diazinon in these samples were negligible (Lisa Ross, California Department of Pesticide Regulation, written commun., 1993). Based on a dye-tracer study completed under a similar flow regime, it is possible that the Stanislaus and Tuolumne Rivers could have carried the diazinon measured at the San Joaquin River near Vernalis if the concentrations were low on the rising limb and high on the decreasing limb.

Additional storm sampling was done on February 18 and 19 during the first significant rainfall following the February 7 storm (fig. 4). The Orestimba Creek site was sampled during this storm to determine if any residual diazinon was being transported to the San Joaquin River during this rainfall and to collect additional samples at peak discharge to verify relatively low concentrations attributable to dilution from Coast Ranges runoff. The highest concentration of diazinon, $0.2 \mu \mathrm{g} / \mathrm{L}$, was measured at the creek site prior to the steep rise of the hydrograph and was much less than the highest concentration observed during the previous storm. This lower concentration indicates that much of the available diazinon load was transported during the February 7 storm. Following the concentration peak, diazinon concentration levels decreased by an order of magnitude and remained low throughout peak discharge. Chlorpyrifos was not detected at Orestimba Creek during this second storm.

The highest concentration of diazinon measured at the San Joaquin River site during the storm of February 18 and 19 was just under $0.4 \mu \mathrm{g} / \mathrm{L}$, considerably less than the maximum concentration measured at this site during the previous storm. Basin-wide response, as indicated by the diazinon concentrations measured in samples from the San Joaquin River at Vernalis, was less than during the previous storm; the reduced response indicates that, throughout the basin, most of the available diazinon had been transported previously. Chlorpyrifos was not detected at the San Joaquin River near Vernalis.

The Merced River was sampled on February 23 and 26 on the declining part of the discharge hydrograph resulting from the February 18-19 storm. The concentration of diazinon rose from a pre-storm level of $0.009 \mu \mathrm{g} / \mathrm{L}$ to $0.19 \mu \mathrm{g} / \mathrm{L}$. The chlorpyrifos concentration rose from less than detectable to $0.033 \mu \mathrm{g} / \mathrm{L}$.

Data from this second storm indicate that much of the diazinon was transported to the San Joaquin River during the previous storm, which is supported by the relatively lower concentrations of diazinon at the Orestimba Creek, Merced River, and San Joaquin River sites. Data for Orestimba Creek support the hypothesis that low concentrations occur at peak discharge in streams of the western San Joaquin Valley. Peak discharge at Orestimba Creek that originated from the Coast Ranges resulted in the dilution of pesticide concentrations measured at the downstream Orestimba Creek sampling site.

The calculated amount of diazinon transported by the San Joaquin River, as measured near Vernalis, was 104 pounds during the month of February. This 
amount of diazinon represents about $0.1 \%$ of the total applied within the drainage of the perennial reach of the San Joaquin River, based on 1990 data, the most recent available. Only a relatively small amount of the applied diazinon was mobilized to the river by rainfall. Nevertheless, during the 1992-93 dormantorchard season, the amount was sufficient to result in toxic levels for at least one aquatic organism.

\section{SUMMARY AND CONCLUSIONS}

This study of pesticides for the dormant-orchard period indicates certain patterns of loading during runoff for parts of the San Joaquin Valley; however, further research is necessary. Diazinon concentrations in the western tributaries to the San Joaquin River increase during the rising part of the storm hydrograph and tend to decrease rapidly as flow from the Coast Ranges increases, relative to locally derived valley runoff. The first major storm following pesticide application mobilizes most of the diazinon that is available to be transported from the orchards. At present, specific factors, especially at the field level, that promote diazinon transport during rainfall are unknown. Further understanding of the pesticide contribution of dormant orchards to the large eastern tributaries, such as the Merced River, could increase the understanding of the San Joaquin Valley drainage system. Preliminary data indicate that pesticide input from the Merced River may be important, but has not been verified by additional sampling.

Data indicate that toxic levels of diazinon can be present along most of the perennial reach of the San Joaquin River during the winter season. This presence occurred during the 1992-93 dormant orchard period because most pesticides were applied during a narrow window of time and a heavy rainfall occurred shortly after the applications. Runoff from one major storm carried the greatest amount of pesticides to the river. The results of this study demonstrate the necessity of selecting the proper sampling frequency to assess the relative contribution of individual drainages to the loading of toxic water to the San Joaquin River. The response time of the tributaries of the western San Joaquin Valley is rapid and occurs within a period of several hours. The only" way to assess the concentrations of toxic compounds is to sample the river or streams during a storm. In contrast, assessing the response of the basin to a storm is relatively easier, because elevated pesticide concentrations usually reach the San Joaquin River at Vernalis a day after the storm. Nevertheless, twice daily sampling, separated in time, was the minimum required during the storm to document that there were at least two major sources of pesticides.

\section{REFERENCES CITED}

Amato, J. R., Mount, D. I., Durhan, E. J., Lukasewycz, M. T., Ankley, G. T., and Robert, E. D., 1992, An example of the identification of diażinon as a primary toxicant in an effluent. Environmental Toxicology and Chemistry, vol. 11, pp. 209-216.

Buchel, K. H., 1983, Chemistry of Pesticides. New York, John Wiley and Sons, $581 \mathrm{p}$.

California Department of Pesticide Regulation, 1990, Pesticide use data. Computer tapes available from California Department of Pesticide Regulation.

Crepeau, K. L., Kuivila, K. M., and Domagalski, J. L., 1994, Methods of Analysis and Quality-Assurance Practices of the U.S. Geological Survey Organic Laboratory, Sacramento, California--Determination of pesticides in water by solid-phase extraction and capillary-column gas chromatography/mass spectrometry. U.S. Geological Survey Open-File Report 94$362,17 \mathrm{p}$.

Domagalski, J. L., and Kuivila, K. M., 1993, Distributions of Pesticides and Organic Contaminants Between Water and Suspended Sediment, San Francisco Bay, California. Estuaries, vol. 16, pp. 416-426.

Edwards, T. K., and Glysson, G. D., 1988, Field methods for measurement of fluvial sediment: U.S. Geological Survey Open-File Report 86-531, 118 p.

Marshall, W. K., and Roberts, J. R., 1978, Ecotoxicology of Chlorpyrifos. National Research Council of Canada Associate Committee on Scientific Criteria for Environmental Quality, NRCC Publication 16079, NRCC/ CNRC Publications, Ottawa, Ontario, Canada, 314 p.

Moody, J. A., and Goolsby, D. A., 1993, Spatial Variability of Triazine Herbicides in the Lower Mississippi River. Environmental Science and Technology, vol. 27, pp. 2120-2126.

Pereira, W. E., and Hostettler, F. D., 1993, Nonpoint Source Contamination of the Mississippi River and Its Tributaries by Herbicides. Environmental Science and Technology, vol. 27, pp. 1542-1552. 
Pereira W. E., and Rostad, C. E., 1990, Occurrence, Distributions, and Transport of Herbicides and Their Degradation Products in the Lower Mississippi River and Its Tributaries. Environmental Science and Technology, vol. 24, pp. 1400-1406.

Readman, J. W., Kwong, L. L. W., Mee, L. D., Bartocci, J., Nilve, G., Rodriguez-Solano, J. A., and GonzalezFarias, F., 1992, Persistent Organophosphorous Pesticides in Tropical Marine Environments. Marine Pollution Bulletin, vol. 24, pp. 398-402.
Richards, R. P., and Baker, D. B., 1993, Pesticide Concentration Patterns in Agricultural Drainage Networks in the Lake Erie Basin. Environmental Toxicology and Chemistry, vol. 12, pp. 13-26.

Thurman E. M., Goolsby, D. A., Meyer, M. T., and Kolpın, D. W., 1991, Herbicides in Surface Waters of the Midwestern United States: The Effect of Spring Flush. Environmental Science and Technology. voi. 25, pp. 1794-1796. 